\title{
The Effectiveness of Using Flipped Classroom Model on Iranian EFL Learners' English Achievements and Their Willingness to Communicate
}

\author{
Jahangir Mohammadi ${ }^{1}$, Hossein Barati ${ }^{1} \&$ Manijeh Youhanaee ${ }^{1}$ \\ ${ }^{1}$ Faculty of foreign languages, University of Isfahan, Isfahan, Iran \\ Correspondence: Hossein Barati, Faculty of foreign languages, University of Isfahan, Isfahan, Iran.
}

Received: March 3, 2019 Accepted: April 14, 2019 Online Published: April 16, 2019

doi: 10.5539/elt.v12n5p101 URL: https://doi.org/10.5539/elt.v12n5p101

\begin{abstract}
This study aims at investigating the influence of using flipped classroom model on Iranian EFL eleven graders' English achievements and their willingness to communicate. A pre-experimental design was used in this study. The participants were students in four classes of two high schools in Sanadaj, Iran. Two classes functioned as experimental and two others as control. The students in the experimental group $(\mathrm{N}=48)$ received instructional videos based on their English textbook. The videos were uploaded on a social network channel made by the researcher so the students could download them and watch them at their convenience time. Each individual participant in the experimental group then had the opportunity to interact with his classmates and teacher via the social network made by the students. This could help the students in the experimental group for the in-class discussion formed on the content of the videos and textbook exercises, Meanwhile, the students in the control group ( $\mathrm{N}=47)$ received in-class traditional teaching focusing on lectures and explanations by the teacher. Despite these two different ways of presenting the contents of the English textbook, students in both experimental and control groups had the opportunity to take part in various learning activities in each classroom session including collaborative activities, completing the textbook exercises, giving comments and presenting new ideas, giving each other support and feedback and taking in-class quizzes. Statistical analysis of the post- test results revealed that the participants in the experimental group could outperform the participants in the control group. Furthermore, the findings of this study indicated that there was a significant difference in learners' willingness to communicate between experimental and control groups in favor of the experimental group.
\end{abstract}

Keywords: flipped classroom, flipped learning model, fundamental reform document of education (FRDE), willingness to communicate

\section{Introduction}

In 2012 the national curriculum was developed based on the fundamental reform document of education in Iran. Safarnavadeh, Asgari, Moosapour and Anani Sarab (2009) maintain "This development was a turning point in the history of foreign language teaching in Iran since it gave a real position to foreign language teaching. Thus, for the first time two pages (pages 37 and 38) of this national curriculum have been devoted to the domain of foreign language teaching and learning while previously the goals and objectives of foreign language teaching had never been stated in any formal document" (cited in Eghtesadi, 2017).

In the national curriculum it is clearly stated "Language teaching lays emphasis on communicative ability and problem solving so that after instruction, the individual is capable of conveying and interpreting meaning using all language skills including listening, speaking, reading and writing" (The National Curriculum, p. 37, cited in Eghtesadi, 2017). Eghtesadi (2017) also states "on page 38 of the curriculum an active and self-relying communicative approach is introduced as the approach to foreign language teaching in Iran. Thus, based on these guidelines in the national curriculum, the Bureau of Textbook Compilation has developed an 88- page document for foreign language teaching program at high schools in Iran. The document emphasizes the change toward a communicative approach program or communicative language teaching (CLT) and marks the beginning of a dramatic change, which demands different responsibilities on the part of teachers and students" (p. 39).

Although the main curriculum aimed at bringing about a methodological and cultural textbook change, it has neglected important issues in terms of personnel and time. Davari and Aghagolzadeh (2015) argue "Our review of 
the gulf between inconsistent policies and questionable practices indicates that success is not guaranteed. The system has ignored important implementation factors, as noted below, casting further doubts on the Iranian education system's chance to succeed" (quoted in British council, 2015: 18).

"First, in the context of Iranian high schools, it was found that EFL learners are deprived of interaction opportunities and do not actively participate in classroom activities. Students are considered more as passive receivers of knowledge and most classroom talk is by the teacher" (Mohabbatsafa \& Hüttner, 2015 cited in British council, 2015, p. 73).

"Another challenge was the limited number of English hours in the curriculum: two hours a week for 26 weeks in the academic year, was far below the minimum requirement for sufficient exposure to the target language in a CLT classroom. The limited time was a serious drawback in that it was neither possible for the teachers to reduce the topics in the textbook from what was assigned by the Ministry of Education, nor was it sensible to expect the teachers to cover the content and achieve the objectives defined by that organization" (Foroozandeh \& Forouzani, 2015, cited in British council, 2015). All this shows that two-hour session a week does not suffice and hence the English proficiency targeted by the curriculum is unlikely to be achieved (Mazdayasna \& Molaei, 2015; Foroozandeh \& Forouzani, 2015; Zandian, 2015, cited in British council, 2015). "A new planning approach is therefore needed that either accepts the lack of learning time and consequently suggests realistic curriculum objectives or, alternatively, increases the number of hours to meet the desired proficiency outcomes" (p. 8).

Davari and Aghagolzadeh (2015) further mantain "The issue of time allocation also raises some important questions. Implementing a communicative approach, especially in those societies where English is a foreign rather than a second or additional language, involves substantial time allocation to increase students' proficiency. In this new curriculum the allocated time, instead of being increased, has been decreased" (cited in British council, 2015: 17). Kaplan and Baldauf (1997) suggest "most foreign language education worldwide is delivered at the rate of three 50-minute periods each week" (quoted in British council, 2015: 17). The average time in the Iranian education system is around 90 minutes per week.

Furthermore, since CLT classes demand more interaction opportunities and active participation of students in the learning process, classrooms dominated by teacher talk are no longer favored and students need to be involved in meaningful tasks in educational settings which are characterized by real world stimulation, and authenticity. In addition, As CLT classes emphasize teacher-student and student-student interactions, learners' willingness to communicate (WTC) becomes crucial to their second language acquisition. This is why learner's willingness to communicate along with its relationships with language proficiency has also become a critical debate in recent years.

All the above mentioned issues necessitate the implementation of an instructional model that can free the instructional time and pave the ground for interactive learning activities which enhance EFL students' communicative competence as well as their willingness to communicate. In addition, there are a very limited number of investigations on the effectiveness of using flipped classroom on students' English language learning in high schools in Iran and no studies have investigated the effectiveness of this model on eleventh graders' willingness to communicate. The study of the effect of flipped English classroom model on the learning of Iranian senior high school students is a new venture that needs attention and aims at coping with the challenges the educational system in the EFL context of Iran has encountered in its shift from the traditional method to communicative learning methods prescribed by the national curriculum. The present investigation attempts to contribute to knowledge of the field in this respect while, at the same time, avoiding some of the limitations identified in the previous research. The limitations of the previous studies are discussed as follows:

Firstly, although they had much contributed to the field, these studies have not investigated the effects of implementing a Flipped classroom model on the learners' willingness to communicate which may be crucial for high school students in achieving success in learning English in the CLT classes. Secondly, the EFL teaching/learning context in high schools in Iran has its own characteristics which make it very different from other contexts held elsewhere in the world; hence, encouraging the present researcher to explore the effect of this unique approach on learning in the EFL context of high schools in Iran with its own specific educational system which may vary a lot in terms of the number of teaching sessions per week, how long each session lasts, the equipment and facilities available, learning culture adopted by learners, intentional content designed for students to learn and professional educators involved. 


\section{Literature Review}

\subsection{Flipped Model of Instruction}

Erik Mazur who was a professor in Harward University was the first to provide text files, interactive demonstrations, and problem solutions for his students in early 1990s. His efforts gave each student the opportunity to meet his/her needs by choosing content as he/she liked (Mazur, 1991). Later in 1998, a model was proposed by Walvoord and Anderson in which students had the opportunity to learn content prior to class while the class time was devoted to the processing part of learning.

In 2000, Lage, Platt, and Treglia stated that in an inverted class, events that have traditionally taken place inside the classroom now happen outside it and vice versa. In 2001, Massachusetts Institute of Technology (MIT) designed Open Educational Resources providing learning resources such as books and videos, a step that has influenced the emergence of the flipped classroom model several years later (Bishop \& Verleger, 2013, cited in Sama Zaksreya, 2016). At the end of 2004, Salman Khan, an MIT graduate, uploaded some recorded videos on YouTube to teach math (Bowen, 2012). In 2008, he created a library of free online tutoring videos containing a variety of academic subjects, known as the Khan Academy, which may be viewed as a touchstone of the flipped classroom technique (Ash, 2012, cited in Sama Zaksreya, 2016). Jonathan Bergmann and Aaron Sams (2007) began recording video lectures for students who were absent. The students had to watch these videos prior to class and take notes on them. They were also expected to bring one thoughtful question to share in class. The analysis of the outcomes of the tests taken by these students revealed that students' achievements were improved. Later other students and teachers who used these video lessons found them useful and began making their own video lectures (Tucker, 2012). It was not long before others accepted this model and it gradually became popularized throughout the world. Tucker (2012) stated that the Bill and Melinda Gates Foundation which was supporting Khan Academy became interested in it and soon these funders paid special attention to this model. In fact, the definition of the flipped classroom is structured around "clearing class time for active learning, and helping students in the moment as they are learning" (Bergmann \& Sams, 2012, p. 17). Toto and Nguyen (2009) argue that "the flipped classroom possesses the best qualities of both the lecture model and the active learning model" (quoted in Sama Zaksreya, 2016). "This might be the reason that it is gaining support at all levels of education" (Hoffman, 2014, cited in Sama Zaksreya, 2016). Fulton (2012) also stated that in flipped model the classroom time can be used more efficiently and creatively. "As it utilizes online resources to move lectures outside the classroom, class time is freed up for active learning endeavors such as discussion and problem solving, rather than passive listening” (Arnold-Garza, 2014; Milman, 2012, cited in Sama Zaksreya, 2016).

"Flipped learning has emerged as a unique approach which reverses the role of homework and classroom activities. In conventional instruction, students acquire new knowledge in the classroom, such as via lecture, and practice it at home via homework. In flipped learning, the students acquire knowledge at home, such as via watching videos made by the teacher, and practice the skills in class, where the teacher can easily monitor and correct the student" (Hsieh, Wu, \& Marek, 2016, p. 1). This provides "a dynamic and interactive learning environment where the educator guides students as they apply concepts and engage creatively in the subject matter" (Flipped Learning Network, 2014, p. 1). "When students prepare before class by watching the instructor's videos, they can learn at their own pace because they are able to pause, rewind, and replay the videos at will. Repeated exposure to the learning materials and resources strengthens and deepens the students' understanding of the material. The knowledge can then be applied in a richer scope during in-class activities" (Hsieh, Wu, \& Marek, 2016, p. 1).

According to Anderson and Krathwohl (2001), gaining knowledge and comprehension are regarded as lower levels of cognitive work while application, analysis, synthesis, and evaluation are higher level of cognitive work and in flipped model, students are supposed to do the formers (gaining knowledge and comprehension) outside of class, and devote the class time to the higher forms of cognitive work. Flipping classroom has been described as: "providing students with a video that explains the concepts, structure and skills, so that when they get to class they can get into a real 'workshop' of learning (J.S. Chen Hsieh et al., 2015, p. 2). In this way, "the teacher is on hand to give practical assistance, check progress and pick up common errors:" (Boyer, 2013, p. 28). Educause (2012, p. 1) also refers to the use of videos in flipped classrooms: "Short video lectures are viewed by students at home before the class session, while in-class time is allocated to exercises or discussions. The video lecture is often seen as the basic element in the flipped approach".

\subsection{The Four Pillars of Flipped Model of Instruction}

"The four pillars of flipped class: flexible environment, learning culture, intentional content, and professional educator were the critical theoretical framework of this approach (Hamdan et al., 2013). Chen Hsieh et al. (2015) discuss these four pillars and argue that "in terms of flexible environment, it can provide both an online learning 
community and physical classroom instruction for students to learn specific content knowledge and demonstrate mastery. With regard to learning culture, the flipped instructional design used is a learner-centered approach, where students actively participate outside the classroom in meaningful and collaborative written and verbal activities via an online learning community. The teacher-made videos contain intentional content specifically designed for students to learn and to explore. Finally, the teacher of this model is a professional educator who continually observes student's progress, provides online and in-person feedback, and assesses the students' performance" (p. 2).

\subsection{Components of Flipped Model}

"A flipped classroom teaching model has two components: (1) direct instruction using video lectures while outside the class and (2) active face-to-face learning while inside the class (Sharples et al., 2014, Cited in Sama Zaksreya, 2016). While video lectures play a major role in a flipped class (Educause Learning Initiative, 2012), Tucker (2012) maintains that the way the teacher uses them in an overall approach can lead to their effectiveness. These videos may be selected from websites or recorded by the teachers. In any case students may download them at their convenience time (Halili \& Zainuddin, 2015). Bergman and Sams (2012) mentioned some guidelines regarding the use of video lectures in flipped classrooms. Firstly, they insist on avoiding lengthy videos that can double the students' work load. They also suggest that interactive video lectures are the best to be used in flipped approach. Ash (2012) advises teachers " to find a way to engage students in the videos such as requiring students to take notes on the videos, ask questions about the videos, or engage in discussion about them" (cited in Sama Zaksreya, 2016). "The flipped classroom is more than publishing a video lecture on the Internet. Therefore, teachers ought to pay attention to the other component of the flipped classroom: class time (Slomanson, 2014, cited in Sama Zaksreya, 2016)). Bergmann and Sams (2014) suggest that class time should be devoted to activities which engage students in collaboration and group work.

\subsection{Variations of Flipped Model}

EducationDive.com (2016) has introduced the following seven types of Flipped model to be used for teaching students from elementary levels to doctoral candidates. To find which type is right for our class, we should pay attention to the students' level, motivation, and their access to technology as well as teachers' acquaintance with how to use technology.

1). "The Standard Inverted Classroom: Students are assigned the "homework" of watching video lectures and reading any materials relevant to the next day's class. During class time, students practice what they've learned through traditional schoolwork, with their teachers freed up for additional one-on-one time" (Cited in Panopto, 2016, p. 2).

2). "The Discussion-Oriented Flipped Classroom: Teachers assign lecture videos, as well as any other video or reading related to the day's subject — think TED Talks, YouTube videos, and other resources. Class time is then devoted to discussion and exploration of the subject. This can be an especially useful approach in subjects where context is everything — think history, art, or English" (Cited in Panopto, 2016, p. 2).

3). "The Demonstration-Focused Flipped Classroom: Especially for those subjects that require students to remember and repeat activities exactly — think chemistry, physics, and just about every math class — it is most helpful to have a video demonstration to be able to rewind and rewatch. In this model, the teacher uses screen recording software to demonstrate the activity in a way that allows students to follow along at their own pace" (Cited in Panopto, 2016, p. 2).

4). "The Faux-Flipped Classroom: One great idea Education Drive uncovered is perfect for younger students for whom actual homework might not yet be appropriate. This flipped classroom model instead has those students watch lecture video in class - giving them the opportunity to review materials at their own pace, with the teacher able to move from student to student to offer whatever individual support each young learner needs" (Cited in Panopto, 2016, p. 2).

5). "The Group-Based Flipped Classroom: This model adds a new element to help students learn from each other. The class starts the same way others do, with lecture videos and other resources shared before class. The shift happens when students come to class, teaming up to work together on that day's assignment. This format encourages students to learn from one another and helps students to not only learn what the right answers are but also how to actually explain to a peer why those answers are right" (Cited in Panopto, 2016, p. 2).

6). "The Virtual Flipped Classroom: For older students and in some courses, the flipped classroom can eliminate the need for classroom time at all. Some college and university professors now share lecture video for student viewing, assign and collect work via online learning management systems, and simply require students to attend 
office hours or other regularly scheduled time for brief one-on-one instruction based on that individual student's needs" (Cited in Panopto, 2016, p. 2). .

7). "Flipping the Teacher: All the video created for a flipped classroom doesn't have to begin and end with the teacher. Students too can make use of video to better demonstrate proficiency. Assign students to their record practice role-play activities to show competency, or ask each to film themselves presenting a new subject or skill as a means to "teach the teacher" (Cited in Panopto, 2016, p. 2).

\subsection{Willingness to Communicate}

The concept of WTC is defined as "a stable predisposition toward communication when free to choose to do so" (McCroskey \& Baer, 1985, cited in MacIntyre \& Charos, 1996, p. 7). This concept has attracted a lot of attention in recent years and "is of obvious interest to communicative language teaching (CLT), which places a premium on learning through communicating; learners with a strong willingness to communicate may be able to benefit from CLT while those who are not so willing may learn better from more traditional instructional approaches" (Ellis, R, 2008, p. 698). Dornyei (2005) suggested that developing WTC is "the ultimate goal of instruction" (p. 210). WTC is a complex construct, influenced by a number of other individual difference factors such as 'communication anxiety', 'perceived communication competence' and 'perceived behavioral control'(MacIntyre et al., 1998, quoted in Ellis, 2008). MacIntyre et al. (1998) presented a schematic model of the WTC construct "showing multiple layers of variables (such as those just mentioned) that feed into WTC. In other words WTC is seen as a final-order variable, determined by other factors, and the immediate antecedent of communication behavior" (cited in Ellis, 2008).

Although L2 WTC development followed the examination of L1 WTC, it turned out to be more complex.

(MacIntyre et al., 1998). L2 WTC was defined as "a readiness to enter into discourse at a particular time with a specific person or persons using L2" (MacIntyre et al., 1998). The complex L2 WTC model proposed by MacIntyre et al. (1998) was developed based on McCroskey and Baer's L1 WTC model (1985). This model indicates that learners' willingness to communicate makes them seek out the opportunity to engage in L2 conversation. In this model WTC is considered as a mental process in which multi-layered variables operate. MacIntyre (2007) argued that the model captures the previous literature's kernels of wisdom, which involve the level of conceptualization, intergroup communication processes, and the issue of time.

The trait-like nature view to WTC indicates that this construct is stable across time and situations. However, researchers (e.g., McCroskey and Richmond, 1990) have acknowledged that WTC is also dependent on specific situations. A study by MacIntyre, Babin and Clément (1999) that examined WTC in L1 confirmed the complementary contributions of trait and state variables to WTC. In this study, the researchers examined the trait and state WTC variables through the subjects' voluntary participation in a laboratory and the tendency to participate in a difficult communication task. They suggested that trait WTC initiated the voluntary participation in a laboratory and, when in a particular situation, state WTC determined whether the communication would take place. The results of this study highlight the complementary contributions of trait and state variables to WTC.

\subsection{An Overview of Related Previous Studies}

Hsieh, Vivian Wu and Marek (2016) studied the effect of the flipped classroom on EFL learning. To achieve the aim of the study, the researchers designed an oral training course using the principals of flipped model to teach a wide range of English idioms. In so doing, they provided extensive online written and verbal communication for the participants who were 48 sophomore English majors in two required English oral training classes. A within-subjects research design exposed all participants to learning English idioms by flipped learning, using the LINE smartphone app, and by conventional instruction. The findings of this study revealed that flipped model of instruction made the participants so motivated that participants became more active in using idioms in class. Implementation of this model also significantly improved the idiomatic knowledge of the participants. The findings verified that the flipped model of instruction was successful in achieving the instructional goals of the class.

In another study by Ahmad, (2016), the effect of the flipped classroom model on Egyptian EFL students' listening comprehension ability was investigated. A one-group pre-posttest design was adopted. The participants of this study were thirty-four $3^{\text {rd }}$-year EFL students at the Faculty of Education, at Suez University. The training course designed comprised three successive stages including: planning, implementation and evaluation. Participants were pretested on listening comprehension before the experiment and then posttested after it. A Paired-samples t-test was used to compare between the results of the pre-test and post-test which revealed a statistically significant improvement in participants' listening comprehension $(\mathrm{t}=11.341, \mathrm{p}<0.05)$ in favor of the 
posttest. The findings revealed that the implementation of the flipped classroom enhanced the listening comprehension of Egyptian EFL students.

The flipped classroom strategy was applied in teaching English grammar to examine its impact on secondary school students' performances, perceptions, and attitudes toward learning English independently by Al-Harbil and Alshumaimeril (2016). The researcher uploaded instructional videos selected based on the students' textbook on the Edmodo site. By downloading these videos, the students had the opportunities for learning the content of their textbook in active interactions. While the students in the control group just received in-class traditional teaching, the experimental group participants learnt the materials by watching the videos provided for them before coming to their class. They also practiced what they had learned under the teacher's supervision by completing collaborative and competitive tasks in groups or pairs. The results revealed that implementing the flipped classroom strategy enhanced the students' grammar performances. Although the mean score of the experimental group was higher than that of the control group, this difference was not statistically significant. The attitudes of students' towards using the flipped model was investigated using semi-structured interviews and a questionnaire. The findings verified that they developed positive attitudes towards flipped classroom strategy in the EFL class.

In another study, Abaeian and Samadi (2016) examined the effect of flipped classroom on Iranian EFL learners' L2 reading comprehension with different Proficiency level. The participants were 100 females EFL learners. They were divided into experimental and control groups. Firstly, a pre-test was administered and after 18 sessions of treatment, the posttest was given to learners. The results indicated, that the experimental group performed significantly better than the control group. Also, the intermediate learners benefit from flipped technique more than upper intermediate learners.

Another study by Mehrnoosh Karimi (2017) aimed at investigating the effect of flipped model of instruction on EFL learners' reading comprehension ability and their attitudes toward flipped model of instruction. In this regard, a sample of 50 EFL learners studying at an accredited private language institute in Isfahan were selected as the participants of the study. They were homogenized through a sample of PET. They were assigned into experimental and control groups. Each group included 25 learners. A researcher-made reading comprehension test was given to the participants as the pretest of the study. The experimental group received flipped model of instruction, whereas the control group received traditional model of instruction. At the end of the study, the researcher-made reading comprehension test was administered to the two groups of the study as their posttest. In addition, to investigate the EFL students' attitude towards the flipped model of instruction, the participants completed a questionnaire on flipped model of instruction. The results of ANCOVA revealed that flipped model of instruction enhanced the reading comprehension ability of EFL students. The findings verified that participants developed positive attitudes towards flipped classroom strategy and find it helpful in many ways.

The purpose of another study by Malahat Yousefzadeh (2015) was to investigate whether the flipped learning had effect on students' learning outcome in different subject matters such as Arabic, English, Math, Science and Geography. To this end, a sample of 250 students and five teachers from a secondary school in Ardabil were selected. They were homogenized on the basis of their last year scores. They formed ten classes including 25 students each. Meanwhile, each teacher was in charge of two classes in which different instructional models were implemented using flipped model in one and traditional model in another. To compare the overall performances of two classes in each subject, T- test was used. The findings revealed that learners in the flipped classes outperformed the students in the ordinary classes.

Although many studies have much contributed to the field, no studies have investigated the effects of flipped classroom model on Iranian EFL eleven graders' achievements, and their willingness to communicate. The present study attempts to investigate if the flipped model of instruction can have any contributions to the enhancement of Iranian EFL eleven graders' achievements, and their willingness to communicate. To this end, a holistic training course was designed in which students learnt the content of their English book before coming to class by watching video lectures provided by the teacher and participating in the interactions held via the social network groups. They spent their class time doing homework, discussing the video lectures and solving questions. In practice, the researcher analyzed the outcomes of an achievement test and one questionnaire taken by two groups of these students in two different learning models (traditional vs flipped). For the experimental group, flipped classroom model was used while the control group was taught using the traditional model. The researcher wanted to find out if there was any significant difference in the students' learning outcomes and their willingness to communicate. 


\section{Research Questions and Hypotheses}

The goal of this study is to find adequate answers to the following questions;

(1) Does implementing flipped classroom model significantly affect senior EFL high school students' English achievements?

(2) Does flipped model of instruction significantly affect senior EFL high school students' willingness to communicate?

To investigate the two above questions of this study the following hypothesis are formulated.

H1: Implementing flipped classroom model significantly improves senior EFL high school students' English achievements.

Ho2: Implementing flipped classroom model does not significantly improve senior EFL high school students' willingness to communicate.

\section{Method}

\subsection{Design of the Study}

This study fairly meets the conditions of pre- experimental studies since intact classes are used and students are assigned to control and experimental groups without randomization. It enjoys a posttest-only pre-experimental design. This study used a convenience sample of four non-equivalent but comparable classrooms which were chosen from two high schools in Sanadaj in Iran.

\subsection{Participants}

This study included 95 (male and female) eleventh grade high school students majoring in three different fields of study, i.e. Humanities, Natural Science, and Math with the age range of 16-17. They were studying at two different high schools in Sanandaj. 49 female students from Sadegh Vaziri high school comprised two classes, one including 24 students and the other including 25 students. The other participants who comprised two classes including 23 eleven graders each, were 46 male students from Shahid Beheshti high school. These students were mostly native speakers of Kurdish who could speak Persian fluently as well. One female class from Sadegh Vaziri high school and one male class from Shahid Beheshti high school including 48 male and female students were chosen as the experimental group and the other two classes including one male and one female class from these two high schools were chosen as the control group of the study. All classes were taught by the same teacher and used the same syllabus and textbook which was "Vision 2 English for Schools". In addition a quick Oxford placement test (Version 2) designed by University of Cambridge Local Examination Syndicate (UCLES) was taken by all participants in both experimental and control groups to assess the comparability of these groups in terms of their levels in English. The results of this placement test did not show significant differences between the experimental and control groups in regards to their levels in English.

\subsection{Materials and Procedure}

In order to meet the instructional outcomes of the flipped classroom for the experimental group, the following adopted procedure was followed by the teacher:

1). A version of Oxford Placement Test (OPT) was administered to both experimental and control groups to determine if there were significant differences between them regarding their levels in English.

2). The English textbook "Vision 2 English for Schools" developed by the Ministry of Education for tudents in grade eleven was used in this study. This book includes three units. Each unit consists of different parts including three sections; "New Words and Expressions", "Reading" and "Vocabulary development". The first two units of the book were taught during the first semester of the study year (2017-2018). The treatment lasted for three months. Each reading text began with pre-reading questions and proceeded through a set of carefully sequenced post-reading activities.

3). For the online learning platform in which the interaction took place, the instructor chose and introduced the most popular Telegram app which was available to many users in Iran. He introduced a Telegram channel for uploading/downloading the instructional videos developed by the teacher. Meanwhile, two separate Telegram groups were made by the students in the experimental group, one for male students from Shahid Beheshti high school and the other for female students from Sadegh Vaziri high school, which were used to give the participants the opportunity to interact with their classmates and their teacher in the cases they had any problems with understanding and learning the content of each unit. This step helped all the students in the experimental group by giving them the opportunity to raise their questions and ask for clarifications. They had to ask their 
classmates first and if nobody contributed, the teacher intervened. These two Telegram groups could provide text, picture and video messaging among students and teachers. These messages focused on the learning of the content of the selected textbook. The teacher also participated in the students' Telegram groups to provide timely and constructive written feedback whenever necessary and to observe the students' online peer interaction.

4). The teacher provided instructional video presentations for his experimental students to watch before class sessions. These videos focused on the presentation of three sections of the first two units ("New Words and Expressions", "Reading" and "Vocabulary development"). The videos were uploaded on the Telegram channel introduced to the students in the experimental group at least one week before the physical class session. All students had to watch these videos before coming to their English class. The teacher was also committed to provide the students with CDs including the instructional videos in the cases they found it difficult to download the videos from the Telegram channel developed. After watching these videos individually, students could also have the opportunity to interact with their classmates and their teacher via the Telegram groups introduced previously.

5). The experimental students came to class and the beginning of each class session was devoted to interactive discussions about the videos so that the teacher could figure out whether all students had watched the videos or not, during the discussion, the teacher clarified any misunderstood points and answered the students' questions. Afterwards, students were asked to complete the textbook and workbook exercises in groups and exchange their books for peer-correction. The teacher walked around the class to observe the students and provide feedback. In addition, the content of the reading passage was discussed followed by doing the pre \&post- reading activities (answering the questions, giving their comments and presenting new ideas). The teacher avoided the traditional inclass lecturing in the flipped English classes for the experimental group.

6). The above mentioned steps were repeated for the following unit of the book so that the whole chosen materials were covered completely

7). On the contrary, in the control group classes the teacher taught the lessons without the help of videos and the students enjoyed the traditional in-class lecturing by the teacher at the beginning of their class session. Afterwards, the teacher asked the students to do some of the textbook activities to check their understanding. Unlike the experimental classes, the presentation of the new lesson took up lots of class time in the control group classes. Since the class time in the control group was not enough to do all the textbook and workbook exercises, the teacher had to assign some of the exercises as homework.

8). In one session, students in both the experimental and control groups took the same achievement post-test covering the units taught. The results were used to assess learners' overall achievements in both experimental and control groups

9). In the second session held one day after administering the achievement test, all eleven graders in experimental and control groups received the WTC questionnaire (willingness to communicate questionnaire) and they were asked to answer the questions attentively.

\subsection{Instruments}

For the purpose of this study, a number of instruments were used which are described below:

Oxford Placement Test (OPT). A version of Oxford Placement Test (OPT, Version 2) designed by University of Cambridge Local Examination Syndicate (UCLES) was administered to the high school eleven graders in both experimental and control groups. This test was used to ensure that the experimental and control group students were comparable in terms of their levels in English.

Achievement Posttest (AT). This test is administered to the participants in both experimental and control groups as a post-test at the end of the study. The test was constructed by the researcher and was related to the topics of the students' textbook taught in the class during the course. The test aimed at measuring the effect of using flipped classroom on reading comprehension ability, vocabulary knowledge and grammar learning of eleventh graders. The total number of the test items was 40 which consisted of 13 grammar questions, 12 vocabulary items and 15 reading comprehension questions. The questions included 9 fill in the blanks items, 6 True/False questions and 25 multiple choice items. Table 1 presents the sub-tests of this achievement test together with their task formats. 
Table 1. Achievement test focus and task format

\begin{tabular}{llll}
\hline Part & Sub Test & No. of questions & Task format \\
\hline 1 & Grammar & 13 & Fill in the blanks and multiple choice items. \\
2 & Vocabulary & 12 & Fill in the blanks and multiple choice items. \\
3 & Reading Comprehension & 15 & True/False questions and multiple choice items. \\
\hline
\end{tabular}

As observed above, the achievement test has three parts. The first part comprised 13 items, aimed at assessing the grammar knowledge of the test takers. These items were developed based on the grammar sections of two units of the eleventh grade English book. The second part comprised 12 items assessing test takers' vocabulary learning and the last part comprised three reading passages which were analyzed for their readability level, using Robert Gunning's Fog Index (1952). This indicated that the texts had a similar readability level as that of the participants' textbook. The test was also piloted with a group of 24 female students from Sadegh Vaziri Senior high school in Sanandaj. These female learners had the same characteristics of the study sample. In light of the statistical results of the pilot study, some items of the test were modified. In addition, decision was made regarding the time allocated based on the performance of the students in the pilot study. The average time needed was 50 minutes for most of the students. The wordings of some of the items were modified based on the suggestions made by experienced teachers and students taking the test. The results of the pilot study were, further, analyzed to assess the validity and reliability of the test. The Cronbach's Alpha coefficient for the reliability estimate for the total achievement test was .924 which is obviously high.

Table 2. Scale: reliability cronbach

\begin{tabular}{lllc}
\hline Case Processing Summary & & \\
\hline & & $\mathrm{N}$ & $\%$ \\
\hline Cases & Valid & 24 & 100.0 \\
& Excluded $^{\mathrm{a}}$ & 0 & .0 \\
& Total & 24 & 100.0 \\
\hline
\end{tabular}

a. List wise deletion based on all variables in the procedure.

Table 3. Reliability statistics

\begin{tabular}{ll}
\hline Cronbach's Alpha & N of Items \\
\hline 924 & 40 \\
\hline
\end{tabular}

In addition, a group of five non-native EFL expert judges were asked to check the content validity of the AT. They were experienced EFL specialists in Applied Linguistics and had taught English to senior high school students for at least five years. They were asked to check the AT items and decide about the correspondence between test items and the content of eleventh grade English textbook. The researcher held a session prior to the task to make the process clear for individual judges. In this session the aims of the study, and their roles were explained in detail and their questions were answered.

Willingness to Communicate Questionnaire (WTC): In order to examine the effect of Flipped classroom model on eleventh graders' willingness to communicate, a questionnaire was developed. Two main sources used for the development of this questionnaire were the qualitative, exploratory data gathered from the participants through recorded semi-structured and focus-group interviews and the questions adapted from the relevant literature.

The construct of willingness to communicate was operationalized as a list of written statements whose format followed a five-point scale (1-5) with (1) representing 'strongly agree', (2) representing 'agree', (3) representing 'neutral', (4) representing 'disagree' and (5) representing 'strongly disagree". The questionnaire was first compiled in English, but later translated into Persian to avoid misinterpretation of the items. To ensure parallelism with the English version of the questionnaire, the questionnaire items were translated by the researchers in this study and subsequently verified by a professional translator. 
To check the content validity of the translated version, five EFL expert judges were asked to decide on the relevance of the questionnaire items to the purpose of the questionnaire. They were all experienced in Applied Linguistics and had taught English to senior high school students for at least five years. Further, they were asked to check the questionnaire for possible wording and interpretation problems with both its items and instructions. This stage resulted in implementing some changes of which the most important were addressing a few wording problems, and changing some of the items of the questionnaire.

In the final form of the questionnaire a brief introduction was given to inform the participants of the aims of the research and participants were asked to provide information regarding their names (optional), age, gender and their field of study. Respondents were asked to answer the 30 items on the 5-point scale presented. This questionnaire was also administered to a total of 30 eleventh grade high school students. Reliability of the whole questionnaire which comprised 30 items was reported to be .93 as estimated through Cronbach Alpha (see the tables below).

Table 4. Case processing summary

\begin{tabular}{llll}
\hline & $\mathrm{N}$ & $\%$ \\
\hline Cases & Valid & 30 & 100.0 \\
& Excluded $^{\mathrm{a}}$ & 0 & .0 \\
& Total & 30 & 100.0 \\
\hline
\end{tabular}

a. Listwise deletion based on all variables in the procedure.

Table 5. Reliability statistics

\begin{tabular}{ll}
\hline Cronbach's Alpha & N of Items \\
\hline .933 & 30 \\
\hline
\end{tabular}

\subsection{Data Analysis}

To answer the two questions of the study which were formulated as (1) Does implementing flipped classroom model significantly affect senior EFL high school students' English achievements?, And (2) Does flipped model of instruction significantly affect senior EFL high school students' willingness to communicate? The performance of the students on the Oxford placement test, posttest and the WTC questionnaire were collected manually and analyzed by SPSS Software version 25. A parametric test, which was the Independent Sample T-test, was used to compare the means of scores of the participants of control and experimental groups on Oxford placement test administered before the treatment and then on the posttest which was administered to both control and experimental groups after the treatment. Finally, for the data collected through the WTC questionnaire, the Independent Sample T-test was used once more.

\section{Results}

\section{1). Results of the OPT test}

Descriptive statistics given in Table 6 comparing the mean scores of experimental groups $(\mathrm{M}=19.77)$ and control groups $(\mathrm{M}=19.61)$ on the OPT test revealed that there is a very slight difference between these groups which is not significant enough. Therefore, it can be used to ensure the comparability of the experimental and control group students in terms of their levels in English before the experiment. The independent sample T-test also confirmed that there was no significant difference between the mean scores of participants in the control and experimental groups for the Oxford placement test. Better to say, the results of this placement test did not show significant differences between the experimental and control groups in regards to their levels in English (See Tables 6 and 7 below).

Table 6. Group Statistics

\begin{tabular}{|c|c|c|c|c|c|}
\hline Group & & $\mathrm{N}$ & Mean & Std. Deviation & Std. Error Mean \\
\hline \multirow[t]{2}{*}{ optmark } & experimental & 48 & 19.7708 & 5.58965 & .80680 \\
\hline & control & 47 & 19.6170 & 4.68371 & .68319 \\
\hline
\end{tabular}


Table 7. Independent Samples T- Test (OPT)

\begin{tabular}{|c|c|c|c|c|c|c|c|c|c|c|}
\hline & & \multicolumn{2}{|c|}{$\begin{array}{l}\text { Levene's Test for } \\
\text { Equalityof } \\
\text { Variances }\end{array}$} & \multicolumn{5}{|c|}{ t-test for Equality of Means } & & \\
\hline & & \multirow[t]{2}{*}{$\mathrm{F}$} & \multirow[t]{2}{*}{ Sig. } & \multirow[t]{2}{*}{$\mathrm{t}$} & \multirow[t]{2}{*}{ df } & \multirow{2}{*}{$\begin{array}{l}\text { Sig. } \\
\text { (2-tailed) }\end{array}$} & \multirow{2}{*}{$\begin{array}{c}\text { Mean } \\
\text { Difference }\end{array}$} & \multirow{2}{*}{$\begin{array}{l}\text { Std.Error } \\
\text { Difference }\end{array}$} & \multicolumn{2}{|c|}{$\begin{array}{l}95 \% \text { Confidence Interval } \\
\text { of the Difference }\end{array}$} \\
\hline & & & & & & & & & Lower & Upper \\
\hline \multirow{2}{*}{ optmark } & $\begin{array}{l}\text { Equalvariances } \\
\text { assumed }\end{array}$ & .826 & .366 & .145 & 93 & .885 & .15381 & 1.05917 & -1.94949 & 2.25711 \\
\hline & $\begin{array}{l}\text { Equalvariances not } \\
\text { assumed }\end{array}$ & & & .145 & 90.844 & .885 & .15381 & 1.05720 & -1.94623 & 2.25386 \\
\hline
\end{tabular}

According to the outcomes presented in Table 6, statistically, there is not a significant difference between the mean scores of participants (eleven graders) in the control group $(\mathrm{M}=19.61, \mathrm{SD}=4.68)$ and experimental group $(\mathrm{M}=19.77, \mathrm{SD}=5.58)$ on the OPT, i.e. $(\mathrm{Sig}=.885>.05)$. This result confirms that the intact classes selected for the experimental and control groups are initially comparable in terms of their levels in English since the results of this OPT did not reveal significant differences between experimental and control groups at (0.05) level. Thus, participants in both groups had similar levels in English prior to the implementation of the treatments.

\section{2). Analysis of Hypothesis 1}

The first hypothesis of this study claims that implementing flipped classroom model significantly improves senior EFL high school students' achievements. To handle the data collected after the treatment, the independent sample T-test was used to measure the statistical differences between the experimental and control groups due to their achievements on a posttest based on the content of their English textbook developed by the Bureau of Textbook Compilation for high school students in grade eleven entitled "Vision 2 English for Schools". The participants' results on the achievement test were recorded and analyzed by the SPSS Software (version 25). Tables 8 and 9 below indicate the outcomes of this analysis.

Table 8. Group Statistics

\begin{tabular}{llllll}
\hline Group & & $\mathrm{N}$ & Mean & Std. Deviation & Std. Error Mean \\
\hline Totaltest & experimental & 48 & 34.1667 & 4.59571 & .66333 \\
& control & 47 & 28.2128 & 9.73996 & 1.42072 \\
\hline
\end{tabular}

Descriptive statistics (Table 8) comparing the means of the experimental and control groups on the post-test revealed that the mean score of the flipped classroom model $(\mathrm{M}=34.16)$ was higher than that of the conventional classroom model $(\mathrm{M}=28.21)$.

Table 9. Independent Samples T- Test (Achievement test)

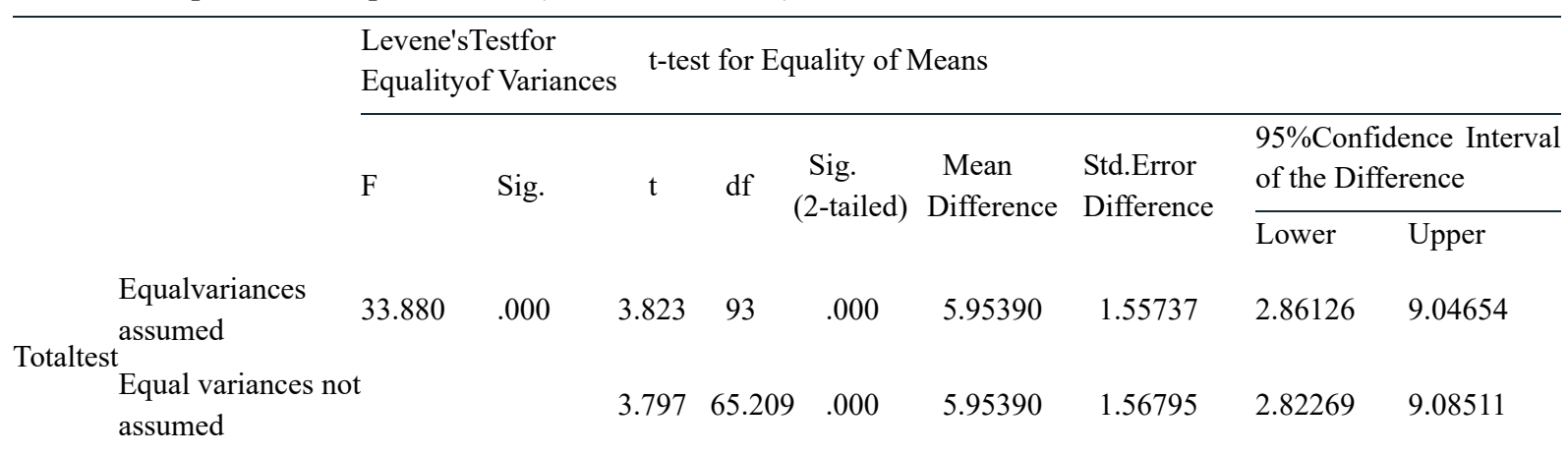

In addition, the independent sample T-test shown in Table 9 indicated that there is a significant difference in favor of the flipped model between the mean scores of participants (eleven graders) in the control group ( $\mathrm{M}=28.21$, 
$\mathrm{SD}=9.73)$ and experimental group $(\mathrm{M}=34.16, \mathrm{SD}=4.59)$ on the posttest, i.e. ( $\mathrm{Sig}=.000<.05)$. This result indicated that the hypothesis which claimed that implementing flipped classroom model significantly improves senior EFL high school students' achievement was confirmed. Therefore based on the results presented in Tables 8 and 9, it can be concluded that the treatment (Flipped classroom model) was effective.

\section{3). Analysis of Hypothesis 2}

The second hypothesis of this study states that implementing flipped classroom model does not significantly improve senior EFL high school students' willingness to communicate. To examine this hypothesis, the mean and standard deviations of the experimental and control groups' achievements on the WTC questionnaire were computed first and independent sample T-test was used to measure the significance of the differences (Tables 10 and 11). The data from the WTC questionnaire was recorded manually and then analyzed by the SPSS Software (version 25).

Table 10. Group statistics

\begin{tabular}{llllll}
\hline Group & & N & Mean & Std. Deviation & Std. Error Mean \\
\hline TotalWTC & experimental & 48 & 121.8125 & 16.27772 & 2.34949 \\
& control & 47 & 101.8723 & 25.33911 & 3.69609 \\
\hline
\end{tabular}

Descriptive statistics (Table 10) comparing the means of the experimental and control groups on the WTC questionnaire revealed that the mean score of the flipped classroom model $(\mathrm{M}=121.81)$ was higher than that of the conventional classroom model $(\mathrm{M}=101.87)$.

Table 11. Independent Samples T- Test (WTC)

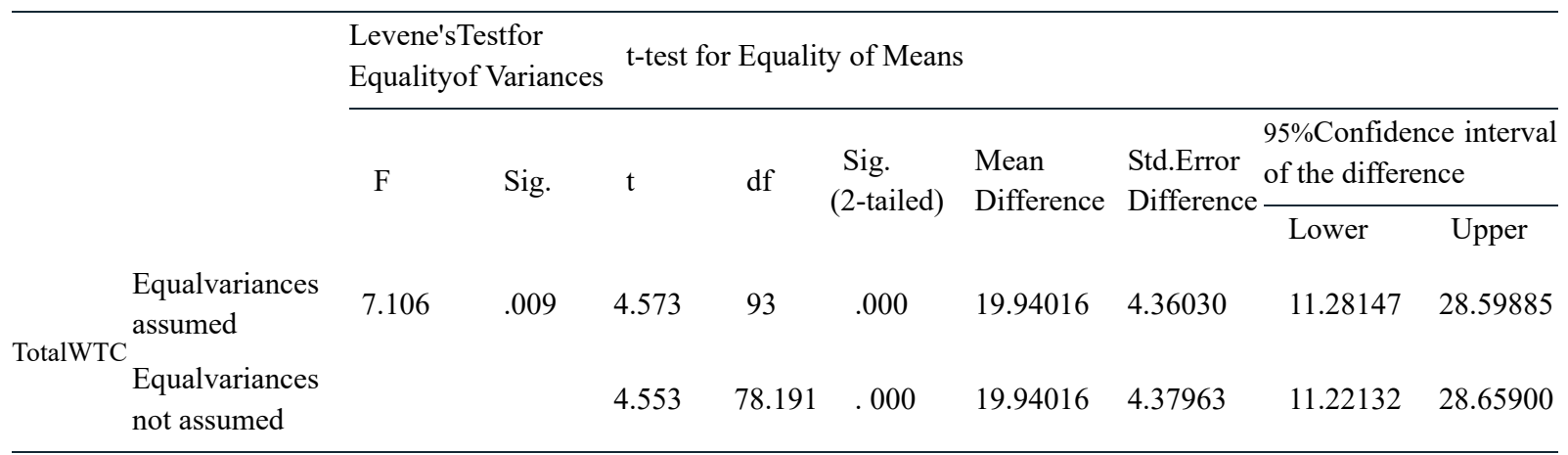

The independent sample T-test in Table 11 revealed that there is a significant difference between the mean scores of participants (eleven graders) in the control group $(\mathrm{M}=101.87, \mathrm{SD}=25.33)$ and experimental group $(\mathrm{M}=121.81$, $\mathrm{SD}=16.27)$ on the WTC questionnaire, i.e. $(\mathrm{Sig}=.000<.05)$. This result rejects the second null hypothesis. Based on the results revealed in Tables 10 and 11, it can be concluded that the treatment (flipped classroom model) was effective in favor of the experimental group.

\section{Discussion}

The aim of this study was to investigate if implementing flipped classroom model could significantly improve senior EFL high school students' English achievements and their willingness to communicate. Findings of the study clearly lend support to the view that implementation of this model enhanced eleven graders' achievements and willingness to communicate because students in the experimental group outperformed participants in control group as indicated by their performance on both the posttest and WTC questionnaire. As to the first question of this study which investigates the effects of flipped classroom model on the improvement of senior EFL high school students' English achievements, the results revealed that in flipped classes, students had more gains on the grammar, vocabulary and reading comprehension questions of the posttest than students in the control group which confirms that the implementation of flipped model can contribute to development of EFL learners' achievements. Regarding the second question of the study which investigates if implementing flipped classroom model significantly improves senior EFL high school students' willingness to communicate, students' 
performance on the WTC questionnaire for the experimental group was compared with that of the control group which indicated a significant difference in favor of the experimental group.

On the other hand, The findings for the first two questions are attributed to the nature of flipped classroom model which follows an instructional procedure that places students at the center of their learning by making them responsible for their prior experiences with learning independently before the real class session through watching instructional videos and taking part in discussions held via the social network groups. This model emphasizes collaborative learning that helps students develop their higher order thinking skills. Furthermore, adopting the flipped classroom strategy can free the instructional time and pave the ground for interactive learning activities which enhance students' communicative competence. In fact, flipped model provides a dynamic and interactive learning environment where the educator guides students as they apply concepts and engage creatively in the subject matter braking down the limitation on time and space. It also could help to adopt a communicative language teaching in EFL classes which is line with the tenets of the national curriculum that put a great emphasis on Learners' communicative ability and problem solving skills in Language teaching.

\section{Conclusion}

The primary objectives of this study were to compare the senior EFL high school students' learning outcomes and willingness to communicate in two groups (experimental and control) which were exposed to flipped and traditional classes respectively. The goal was to assess if there were any differences in the participants' achievements and their willingness to communicate in the experimental and control groups based on the outcomes of one questionnaire and a posttest including three sections devoted to grammar, vocabulary and reading questions. Data for the current study was collected during the fall semester of the educational year (2017-2018) at two high schools in Sanandaj in Iran. Findings from this study indicated that the students in the flipped classes could outperform the control groups' participants on the posttest and the WTC questionnaire. The outcomes of this study suggest that the flipped approach could be a viable methodology for EFL high school students. Students in the experimental group experienced an innovative way of teaching grammar, vocabulary and reading comprehension which offered a practical solution to the problems of EFL learning in high schools in Iran. This study confirmed that flipped classroom model provides more opportunities to use and practice English both inside and outside the classroom while braking down the limitations on time and space which were typical of traditional classes. Furthermore, this study revealed that theory-based flipped instruction using extensive online interaction via the social network group motivated the participants in the experimental group to have a better grasp of the content of the eleventh grade English textbook. The experimental group students' learnt the content of their English textbook much better than students in the traditional classes. Flipped classroom students were engaged in more learning tasks, making them more active and competent in using the learned grammar, vocabularies and reading materials for communicative interaction, storytelling, dialog development, class discussion, and group presentations. In Summary, flipped instruction is an appropriate instructional design for teaching English as a foreign language in high schools in Iran which has started a shift from traditional to communicative methods.

\section{Acknowledgments}

First, I would like to express my gratitude to my dear colleague Ms Nasrin Heidari for generous didcation of her time to participate in this study. Also, I would like to thank the administrators and students from Sadegh Vaziri and Shahid Beheshti high schools in Sanadaj in Iran for their assistance and friendly participating in this study.

\section{References}

Abaeian, H., \& Samadi, L. (2016). The effect of flipped classroom on Iranian EFL learners' L2 reading Comprehension: Focusing on different proficiency levels. Journal of Applied Linguistics and Language Research, 3(6), 295-304.

Aghagolzadeh, F., \& Davari, H. (2014). Iranian critical ELT: A belated and growing intellectual shift in Iranian ELT community. British Council, 11-19.

Ahmad, S. Z. (2016). The flipped classroom model to develop Egyptian EFL Students' listening Comprehension. English language teaching, 9(9), 166-175. https://doi.org/10.5539/elt.v9n9p166

Al-Harbi, S. S., \& Alshumaimeri, Y. A. (2016). The Flipped Classroom Impact in Grammar Class on EFL Saudi Secondary School Students' Performances and Attitudes. English Language Teaching, 9(10), 60-80. https://doi.org/10.5539/elt.v9n10p60

Anderson, L.W., \& Krathwhol, D. R. (2001). A taxonomy for learning, teaching, and assessing: a revision of Bloom's taxonomy of educational objectives. New York: Longman. 
Bergmann, J., \& Sams, A. (2012). Flip your classroom: Reach every student in every class every day. Washington, DC: International Society for Technology in Education.

Bergmann, J., \& Sams, A. (2014). Flipped learning: Maximizing face time. Training \& Development, 68(2), 28-31. Boyer, A. (2013). The flipped classroom: Catering for difference. Teacher Learning Network, 20(1), 28-29.

Dörnyei, Z. (2005). The Psychology of the Language Learner: Individual Differences in Second Language Acquisition. Mahwah, N.J: Lawrence Erlbaum. https://doi.org/10.1177/0261927X05281424

Education Dive.com. (2016). Seven unique classroom models- Which is right for you? Retrieved from https://www.panopto.com/blog/7-unique-classroom- models- right/

Educause, C. (2012). Things you should know about flipped classrooms. Retrieved June 19, 2013, from http://net.educause.edu/ir/library/pdf/eli7081.pdf.

Educause Learning Initiative. (2012). Seven things you should know about flipped classrooms. Retrieved August 23, 2015, from https://net.educause.edu/ir/library/pdf/ELI7081.pdf

Eghtesadi, A. M. (2017). Models of communicative competence: Implications for language teachers and teacher educators. Roshd Foreign Language Teaching Journal, 31(3), 28-40.

Ellis, R, (2008). The study of second language acquisition. Oxford: Oxford University Press.

Flipped Learning Network. (2012). Improve student learning and teacher satisfaction with one flip of the classroom.

Foroozadeh, E., \& Forouzani, M. (2015). Developing school English materials for the new Iranian Educational system. British Council, 58-70. Retrieved from https://.Iran. Britishcouncil.org/sites/default

Fulton, K. (2012). Upside down \& inside out: Flip your classroom to improve student learning. Learning \& Leading with Technology, 39(8), 12-17.

Halili, S., \& Zainuddin, Z. (2015). Flipping the classroom: What we know \& what we don't. The Online Journal of Distance Education \& e-Learning, 3(1), 15-22.

Hamdan, N., McKnight, P., McKnight, K., \& Arfstrom, K. (2013). A review of flipped learning. Retrieved from $\mathrm{http} / / / \mathrm{www}$. flippedlearning.org/review

Hsieh, J. S., Wu, W. C. V., \& Marek, M. W. (2016). Using the flipped classroom to enhance EFL learning. Computer Assisted Language Learning, 1-25.

Kaplan, R. B., \& Baldauf, R. B. (1997). Language Planning: From Practice to Theory. British Council, 11-19.

Karimi, M., \& Hamzavi, R. (2017). The Effect of Flipped Model of Instruction on EFL Learners' Reading Comprehension: Learners' Attitudes in Focus. Advances in Language and Literary Studies (ALLS), 8(1), 95-103. https://doi.org/10.7575/aiac.alls.v.8n.1p.95

Lage, M., Platt, G., \& Treglia, M. (2000). Inverting the classroom: A gateway to creating an inclusive learning environment. Journal of Economic Education, 31(1), 30-43. https://doi.org/10.1080/00220480009596759

MacIntyre, P. D. (2007). Willingness to communicate in the second language: Understanding the decision to speak as a volitional process. Modern Language Journal, 91, 564-576. https://doi.org/10.1111/j.1540-4781.2007. 00623.x

MacIntyre, P. D., Babin, P. A., \& Clément, R. (1999). Willingness to communicate: Antecedents and Consequences. Communication Quarterly, 47(2), 215-229. https://doi.org/10.1080/01463379909370135

MacIntyre, P. D., \& Charos, C. (1996). Personality, attitudes, and affect as predictors of second language communication. Journal of Language and Social Psychology, 15(1), 3-26. https://doi.org/10.1177/ $0261927 X 960151001$

MacIntyre, P. D., Dörnyei, Z., Clément, R., \& Noels, K. A. (1998). Conceptualizing willingness to communicate in a L2: A situational model of L2 confidence and affiliation. The Modern Language Journal, 82(4), 545-562. https://doi.org/10.1111/j.1540-4781.1998.tb05543.x

McCroskey, J. C., \& Baer, J. E. (1985). Willingness to communicate: The construct and its measurement. Paper presented at the annual convention of the Speech Communication Association, Denver, Colorado.

McCroskey, J. C., \& Richmond, V. P. (1990). Willingness to communicate: Differing cultural perspectives. Southern Communication Journal, 56(1), 72-77. https://doi.org/10.1080/10417949009372817 
Mazdayasna, G., \& Forouzani, M. (2015). Developing school English materials for the new Iranian educationalsystem. British Council, 48-56.

Mazur, E. (1991). Can we teach computers to teach? Computers in Physics, 5(1), 31-38. https://doi.org/10.1063/ 1.4822968

Mohabbatsafa, M., \& Huttner, J. (2015). The impact of language games on the nature of interactions in the Iranian EFL primary classroom. British Council, 73-80.

Tucker, B. (2012). The Flipped classroom: Online instruction at home frees class time for learning. Education Next, $12(1), 82-83$.

Walvoord, B. E., \& Anderson, V. J. (1998). Effective grading: A tool for learning and assessment. San Francisco: Jossey-Bass.

Yousefzadeh, M., \& Salimi, A. (2015). The Effect of Flipped Learning (Revised Learning) on Iranian Students' Learning Outcomes. Advances in Language and Literary Studies, 6(5), 209-213.

Zandian, S., (2015). Migrant Literature and teaching English as an international language in Iran. British Council, 113-120.

\section{Copyrights}

Copyright for this article is retained by the author(s), with first publication rights granted to the journal.

This is an open-access article distributed under the terms and conditions of the Creative Commons Attribution license (http://creativecommons.org/licenses/by/4.0/). 